\title{
DYNAMIC AND STEADY-STATE PERFORMANCE OF A PWM CONVERTER-FED SERIES MOTOR
}

\author{
M. M. Khater and S. S. Shokralla \\ Department of Electrical Engineering, Faculty of Engineering, \\ Menoufiya University, Shebin El-Kom
}

\begin{abstract}
This paper introduces an analytical and experimental investigation for both dynamics and steady-state of a dc series motor fed from a single-phase AC to DC pulse width modulated (PWM) voltage source converter. The source impedance as well as the saturation effects were taken into consideration. The differential equations describing the system behavior in the different modes of operation are given. Solving these equations using fourth order Runge-Kutta method enabled the prediction of the motor performance in both transient and steady-state conditions. The large chopping frequency facilitate the input filter requirements of the supply current. The supply current, which is considered sinusoidal, can be controlled with a near unity power factor. The complete performance is verified experimentally where close agreement between the computed and test results is achieved.
\end{abstract}

\section{INTRODUCTION}

Many conventional switching power supplies in data processing equipment and low power motor drive systems operate by rectifying the input AC line voltage and filtering it with Jarge capacitors. This process involves the need of both nonlinear and storage elements and results in generation of distorted input current waveform with rich harmonics. The input power factor of such systems is also poor [1-2].

The use of self-commutated converters, employing controlled on/off power switches such as power transistors, MOSFETs, IGBTs and GTOs challenge thyristor schemes in the available power ratings. The use of these switches with pulse width modulated (PWM) converters can efficiently and economically be employed in low and medium power applications of de drive systems while maintaining the advantages of design simplicity and operation reliability of natural commutated schemes. These switches efficiently compete, with expensive and less reliable, forced-commutated schemes[3-4].

Manuscript received from Dr; M. M. Khater on : 5/6/1999

Accepted on: 17/6/1999

Engineering Research Bulletin, Vol 22,No 3, 1999

Minufiya University, Faculty of Engineering, Shebin El-Kom, Egypt, ISSN 1110-1180 
Many studies were reported for AC to DC PWM converters [5-8]. Analysis and simulation for such systems have not been presented in analytical form in any of these papers. In Ref [5-8] the study were restricted to passive R-L load circuits. Steady-state numerical simulation and performance evaluation of dc drive systems were reported in Ref [9]. The digital simulation of PWM converter-fed separately-excited dc motor is reported in Ref [3]. No attention has been paid to the dynamic performance and speed control of a dc series motor supplied from single-phase AC-DC pulse width modulated converters.

In the present paper, a complete modeling and numerical simulation are obtained for a system which consists of a dc series motor fed from an AC to DC single-phase pulse width modulated converter using two switches (IGBT's) and two diodes. Both the supply impedance and magnetic saturation are taken into account. The differential equations which describe the system are numerically solved using simulation program. The proposed program is used to predict both steady-state, run-up and transient conditions for this system. The simulation results have been verified experimentally and the results are found to be in a good agreement.

\section{SYSTEM DESCRIPTION}

Figure. 1 shows the circuit configuration of a single-phase AC to DC PWM voltage source converter. The circuit consists of two power electronic switches (IGBT's) and two diodes. The switches are in charge of switching the supply voltage on and off according to the PWM reference of the drive circuit, while each diode is used as a complement for the switch of the other leg. A free-wheeling diode is also connected across the motor terminals to circulate the motor current during turn-off periods.

The drive circuit for this system is shown in Fig.2. The generation of the gate pulses is accomplished by comparing a half-wave sinusoidal voltage of variable amplitude $\mathrm{v}_{\mathrm{m}}$ (modulating signal) with a triangle voltage $v_{c}$ (carrier signal). The converter output $d c$ voltage is varied by changing the amplitude of the modulating signal $\left(\mathrm{v}_{\mathrm{m}}\right)$. The simulation and experimental waveforms for the control signals and gate pulses are shown in Fig.3.

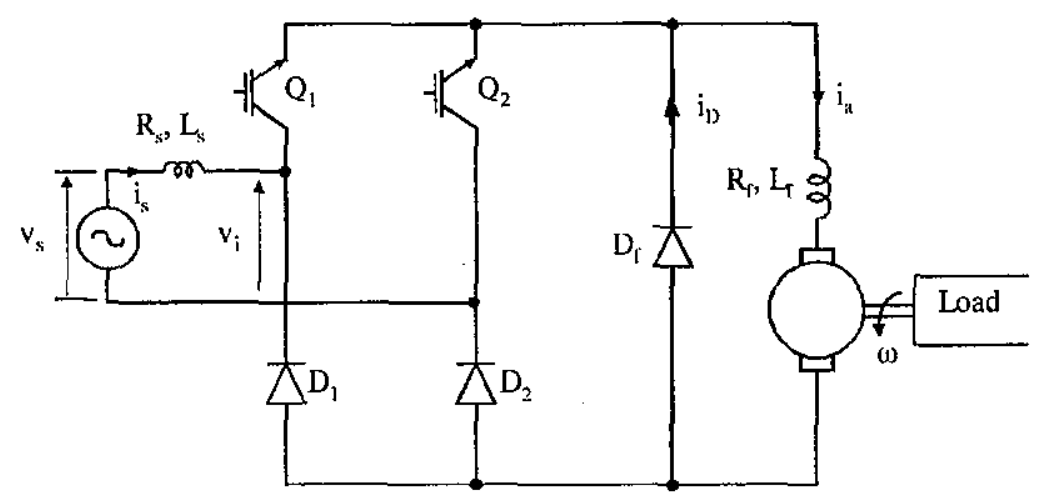

Figure 1. The circuit configuration of a single-phase voltage source converter. 


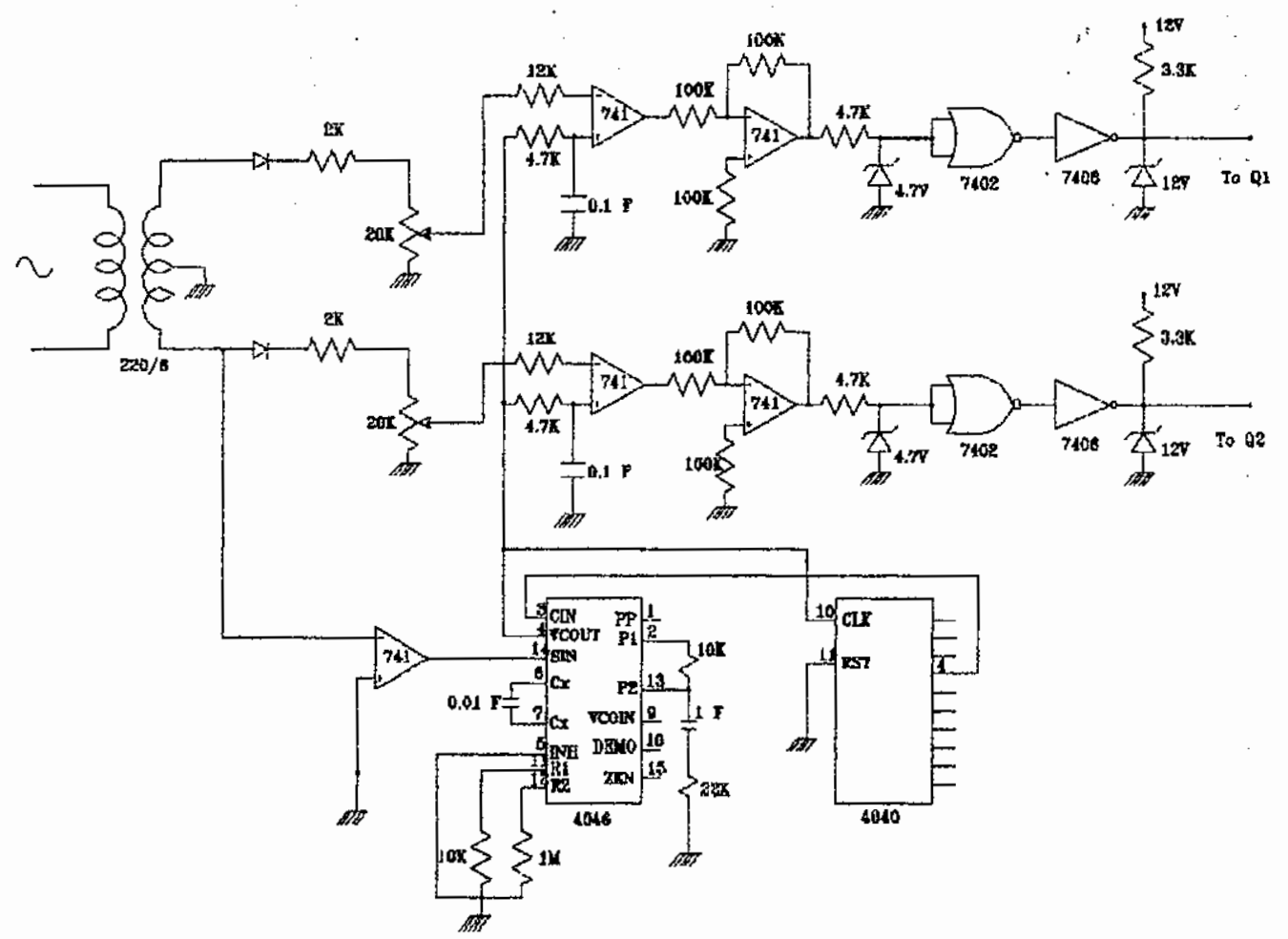

Figure 2. The drive circuit for power electronic switches.
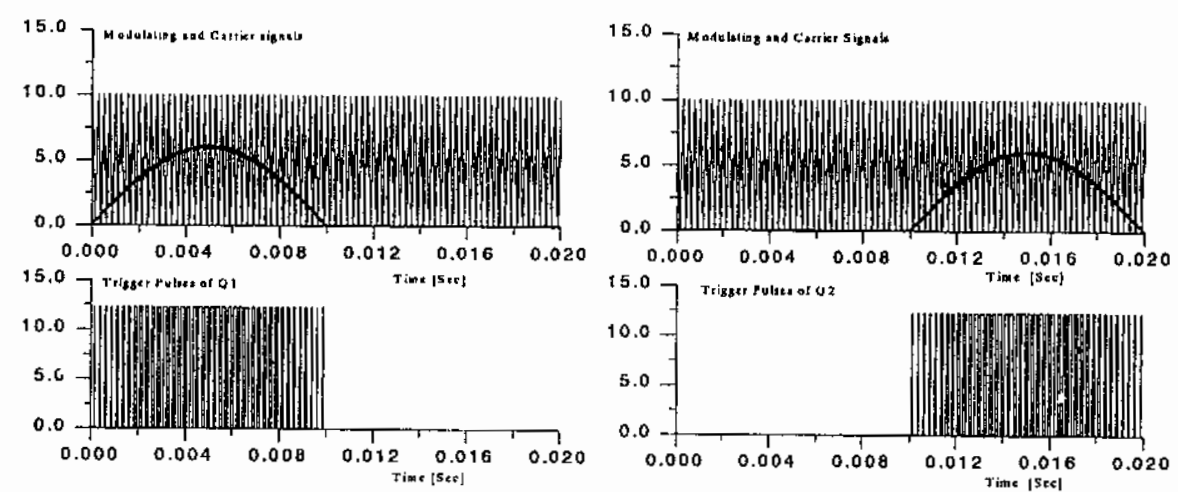

a. Simulation results.

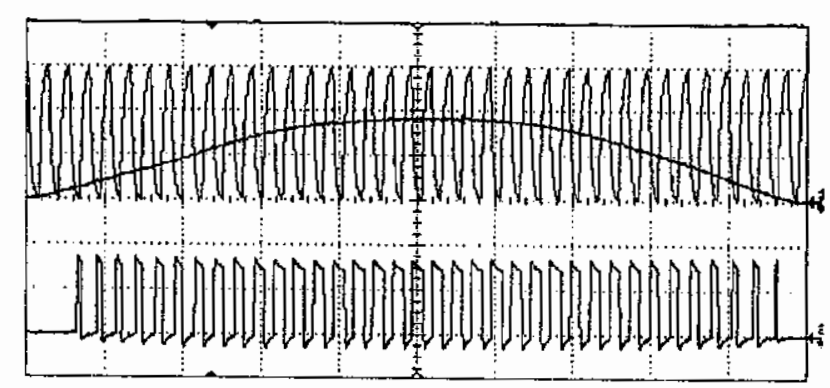

b. Experimental results.

Top: Modulating and carrier signals 5V/div, Bottom: Gate pulses $10 \mathrm{~V} / \mathrm{div}$, Time: $1.0 \mathrm{~ms} / \mathrm{div}$

Figure 3. Simulation and experimental results for the control signals and gate pulses for the two IGBTs. 


\section{SATURATION EFFECTS}

The effect of magnetic saturation is taken into account based on the measured open circuit characteristic of the motor. This characteristic is usually linear at low values of excitation current ( air gap line ) with a back emf constant $\mathrm{K}_{\mathrm{o}}$ Volt/Ampere rad./Sec. At certain value of excitation current, $\mathfrak{l}_{\text {sat }}$, saturation starts and the characteristic becomes nonlinear. For this part of characteristic the back emf constant $\mathrm{K}$ can be obtained from the following expression [10-14];

$e=\left(B+K . i_{a}\right) \omega$

where $\omega$ is the motor speed and B is a motor constant which represents the residual flux (V/rad/Sec). Once the saturation back emf constant $\mathrm{K}$ has been calculated, the saturation factor $\left(\mathrm{K}_{\mathrm{s}}=\mathrm{K}_{\mathrm{o}} / \mathrm{K}\right)$ can be obtained. The motor constant $\alpha$ which identifies saturation can be obtained from the following expression[10-14];

$\mathrm{K}_{\mathrm{s}}=1.0+\alpha\left(\mathrm{i}_{\mathrm{a}}-\mathrm{I}_{\text {sat }}\right)$

The motor inductances $\left(\mathrm{L}_{\mathrm{a}}, \mathrm{L}_{\mathrm{f}}\right)$ are also current dependent in the same manner as the back emf. The motor test parameters, the magnetization curve parameters and the source impedance parameters are given in the Appendix.

\section{SYSTEM MODELING AND MODES OF OPERATION}

Figure. 4 shows the modes of operation which can be demonstrated as given below;

Mode (1)

This mode of operation occurs when either switch $Q_{1}$ or $Q_{2}$ is turned-on as shown in Fig.4.a. The corresponding differential equations are as follows;

$$
\begin{aligned}
& v_{s}=v_{i}+L_{s} \frac{d i_{s}}{d t}+i_{s} R_{s} \\
& v_{i}=L \frac{d i_{a}}{d t}+R i_{a}+B \omega+K \omega i_{a} \\
& L=L_{a}+L_{f} \\
& R=R_{a}+R_{f}
\end{aligned}
$$

where $R_{a}, R_{f}$ are the armature and field resistances respectively (ohms), $L_{a}, L_{f}$ are armature and field inductances respectively (henery) and $i_{s}, i_{a}$ are the supply and motor currents (ampere).

The motor mechanical equation is as follows;

$$
\begin{aligned}
& T_{c}=J \frac{d \omega}{d t}+F \omega+T_{L} \\
& T_{c}=\frac{e i_{a}}{\omega}
\end{aligned}
$$

where $T_{e}$ is the electromagnetic torque $(\mathrm{Nm}), J$ is moment of inertia $\left(\mathrm{Kg} \cdot \mathrm{m}^{2}\right), T_{L}$ is the load torque $(\mathrm{Nm})$ and $\mathrm{F}$ is the motor viscous friction coefficient $(\mathrm{Nm} / \mathrm{rad} / \mathrm{Sec})$. 
Mode (2)

This mode of operation occurs when both switch $Q_{1}$ and $Q_{2}$ are turned-off and terminated when the corresponding diode current is reduced to zero as shown in Fig 4.b. This mode can be expressed by the following differential equations;

$$
\begin{aligned}
& 0=L \frac{d i_{a}}{d t}+R i_{a}+B \omega+K \omega i_{a} \\
& T_{e}=J \frac{d \omega}{d t}+F \omega+T_{L} \\
& T_{e}=\frac{e i_{a}}{\omega}
\end{aligned}
$$

\section{Mode (3)}

This mode of operation occurs when both switch $Q_{1}$ and $Q_{2}$ are turned-off and the current of the free-wheeling diode is reduced to zero as shown in Fig 4.c. The corresponding differential equations are as follows;

$\mathrm{i}_{\mathrm{a}}=0$

$0=J \frac{d w}{d t}+F \omega+T_{l}$

The solution of these nonlinear differential equations is obtained numerically using fourth-order Runge-Kutta integration method.

\section{MODELING OF THE IGBT'S DRIVE CIRCUIT PULSES}

The rectified half wave modulating signal $\left(v_{m}\right)$ for both switches which is represented in Fig 3.a, can be represented by the following expressions;

For switch $Q_{1}$ :

$$
\begin{array}{ll}
\mathrm{v}_{\mathrm{m}}=\mathrm{V}_{\mathrm{m}} \sin \mathrm{x} & \mathrm{n} \pi<\mathrm{x}<(\mathrm{n}+1) \pi, \mathrm{n}=0,2,4, \ldots . \\
\mathrm{v}_{\mathrm{m}}=0 & \mathrm{n} \pi<\mathrm{x}<(\mathrm{n}+1) \pi, \mathrm{n}=1,3,5, \ldots .
\end{array}
$$

For switch $\mathrm{Q}_{2}$ :

$$
\begin{aligned}
& v_{m}=0 \quad n \pi<x<(n+1) \pi, n=0,2,4, \ldots \\
& v_{m}=-V_{m} \sin x \quad n \pi<x<(n+1) \pi, n=1,3,5, \ldots .
\end{aligned}
$$

The triangular carrier signal $\left(v_{c}\right)$ is given by the following equations;

$$
\begin{aligned}
& \mathrm{v}_{\mathrm{c}}=\mathrm{V}_{\mathrm{c}}\left(1+\frac{\mathrm{x}}{\tau / 2}\right) \quad \frac{\mathrm{n} \pi}{\mathrm{NT}}<\tau<\frac{(2 \mathrm{n}+1) \pi}{2 \mathrm{NT}}, \mathrm{n}=0,1,2, \ldots \\
& \mathrm{v}_{\mathrm{c}}=\mathrm{V}_{\mathrm{c}}\left(1-\frac{\mathrm{x}}{\tau / 2}\right) \quad \frac{(2 \mathrm{n}-1) \pi}{2 \mathrm{NT}}<\tau<\frac{\mathrm{n} \pi}{\mathrm{NT}}, \quad \mathrm{n}=1,2,3, \ldots
\end{aligned}
$$

where $\mathrm{x}$ is the instant of intersection in radians, $\left(\mathrm{V}_{c}\right)$ is the peak value of carrier voltage which equals $12 \mathrm{~V}, \mathrm{NT}$ is the number of pulses per supply half cycle and $\tau$ is the chopping period in radians. 


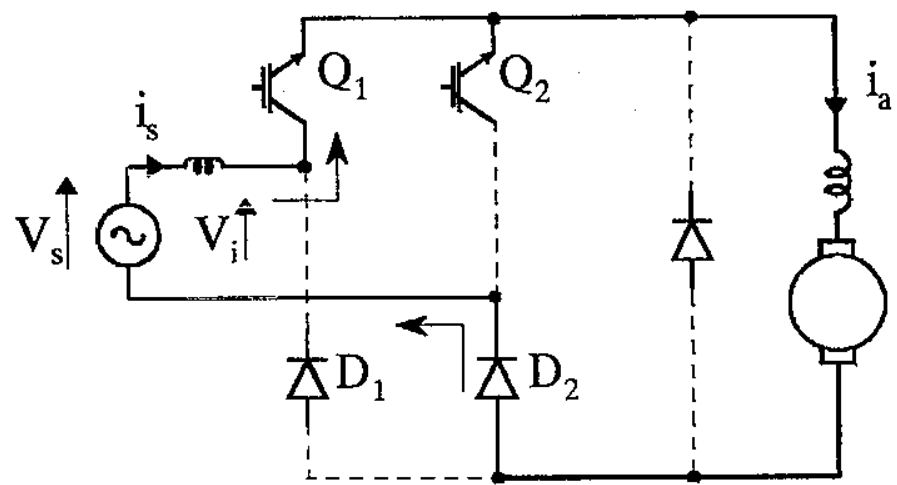

a. Mode 1

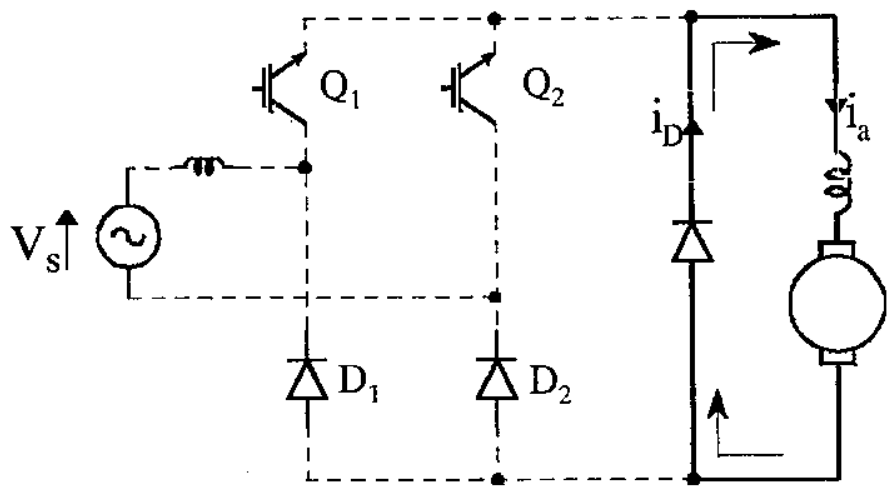

b. Mode 2

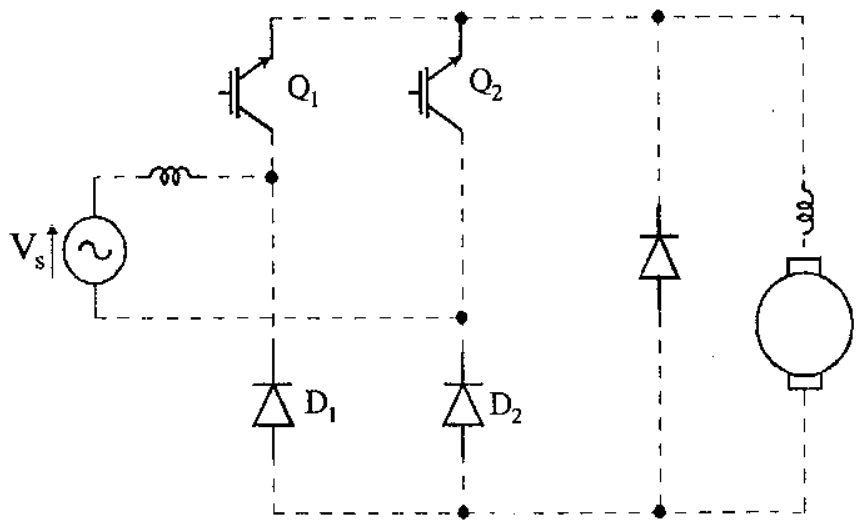

c. Mode 3

Figure 4. Modes of Operation

\section{EXPERIMENTAL AND SIMULATION RESULTS}

The propsed system is designd and built in the laboratory to verify the analysis. The system bchaviour under steady-state, run-up and disturbance conditions is determined by solving the given non-linear differential equations. The instantaneaus and rms values of supply current, motor current, motor voltage, diode current, electromagnetic torque and motor speed are obtained analytically and experimentally. 


\subsection{Steady-State Performance}

Figure 5. shows the simulation and experimental results for variations of the supply input power factor versus load torque. This figure also shows the variation of the current total harmonic distortion factor (THDI) versus load torque. It is observed that the power factor is satisfactory and THDI is almost constant over the load range. This is because a constant modulation index is used.

Figure $\dot{0}$. shows the simulation and experimental results for the variation of supply current and motor input current versus load torque. It noticed that both values are increased with the increase of the load torque. This is due to the constant value of motor applied voltage.

Figure 7. shows the simulation and experimental results for the variation of supply and motor voltage versus load torque. It is observed that the motor voltage is constant due to constant value of the modulation index $M\left(M=V_{m} / V_{c}\right)$.

Figure 8 shows the simulation and experimental results for the motor speed-torque characteristics. These characteristics are obtained with constant modulation index, however the speed can be controlled by varing this index.

Figures $9,10,11$ show the steady-state waveforms of the proposed system. These results are recorded at full load with chopping frequency $4 \mathrm{khz}$ and modulation index 0.6. Figure 9. shows the supply voltage and current waveforms. Figure 10. shows the motor voltage and current waveforms. Figure 11. shows the free wheeling diode current.

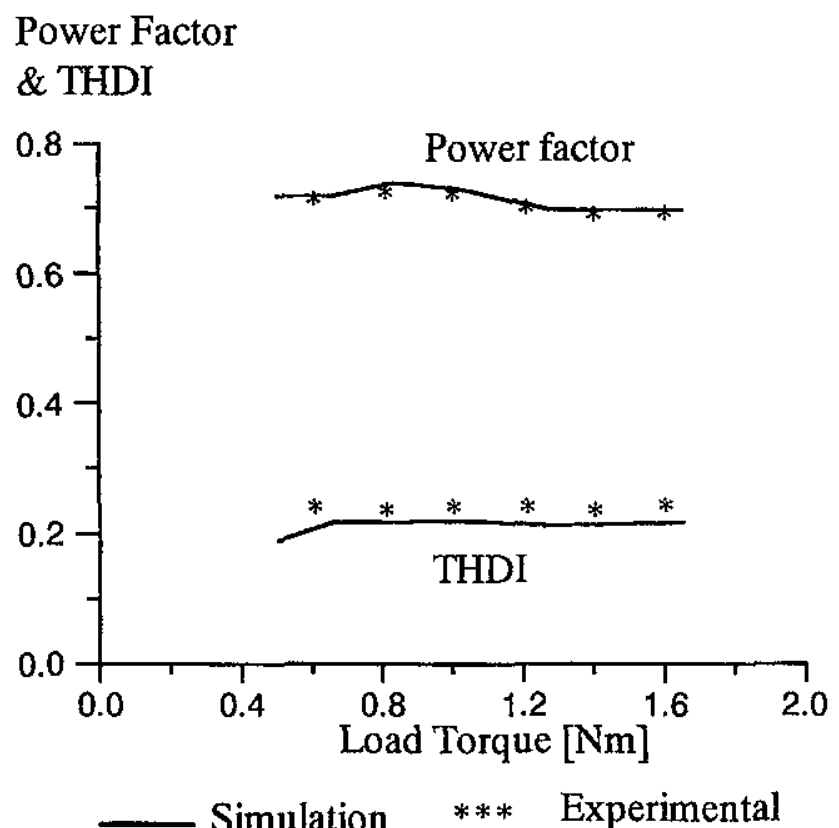

Figure 5. Supply input current total harmonic distortion factor and power factor versus load torque. 


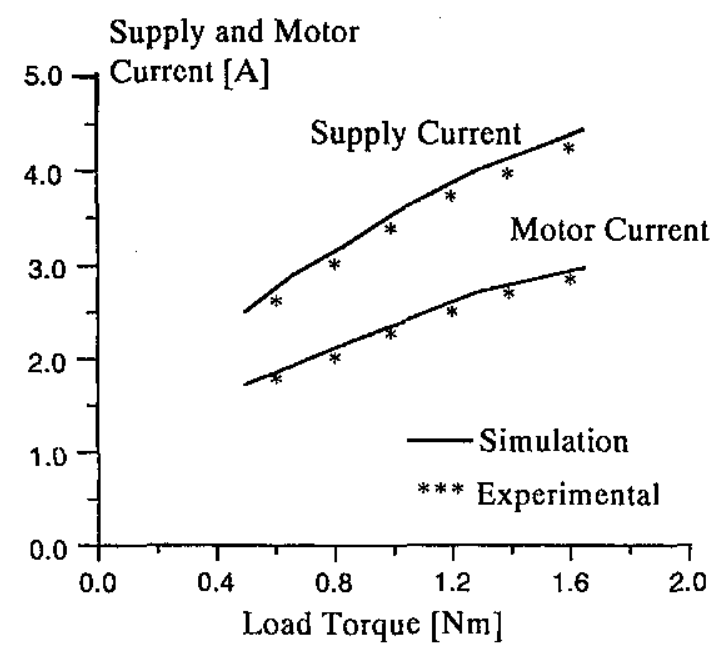

Figure 6. Supply and motor current versus load torque.

Supply and Motor Voltage [Volt]

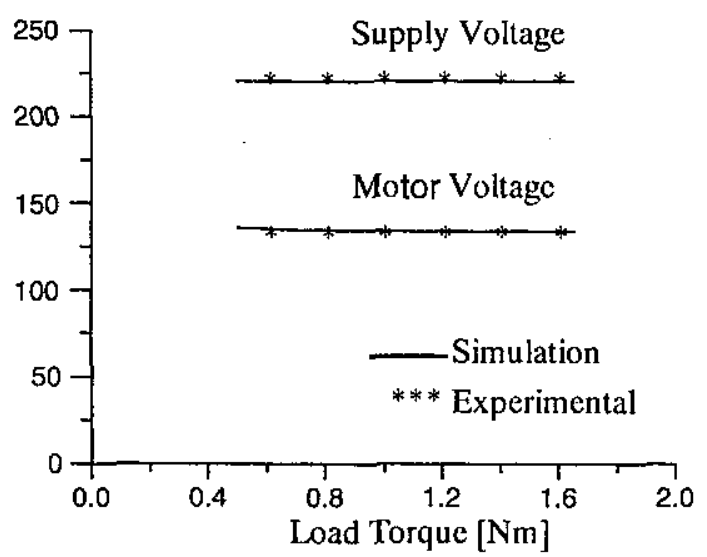

Figure 7. Supply and motor voltage versus load torque.

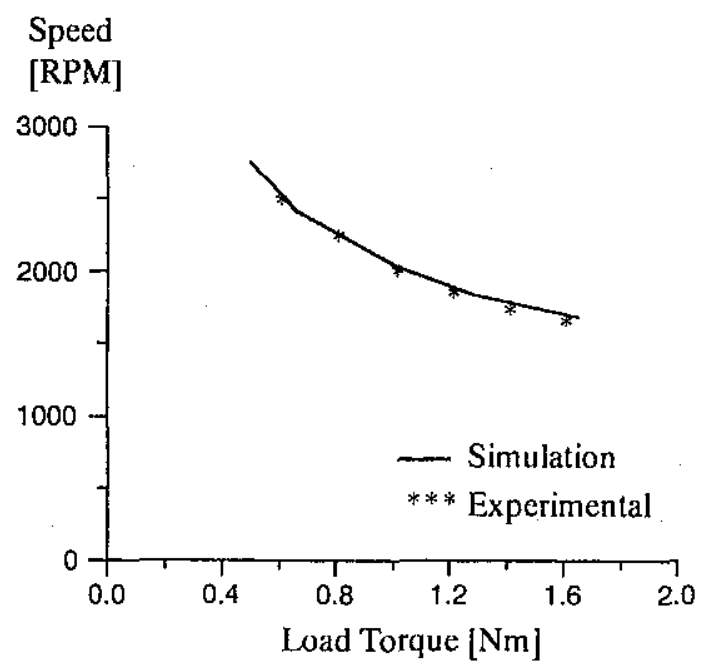

Figure 8. Torque-speed characteristics. 

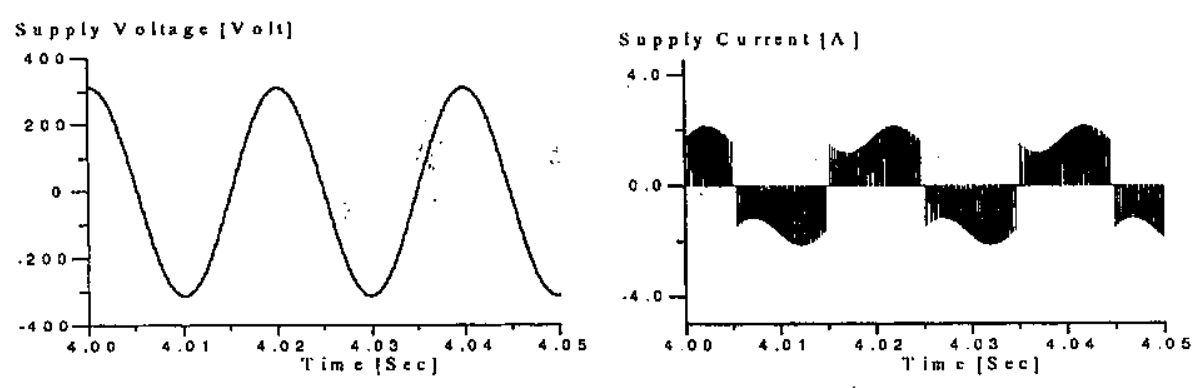

a. Simulation results.

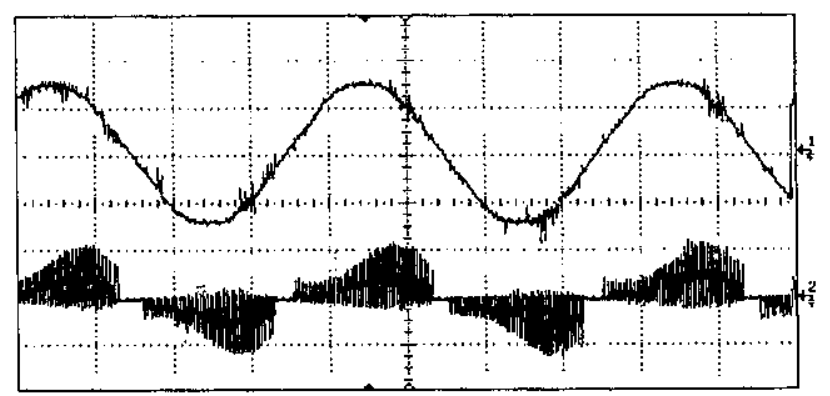

b. Experimental results.

Top: supply voltage $200 \mathrm{~V} / \mathrm{div}$, Bottom: supply current $2 \mathrm{~A} / \mathrm{div}$

Figure 9. Simulation and experimental results for supply input voltage and current versus time.

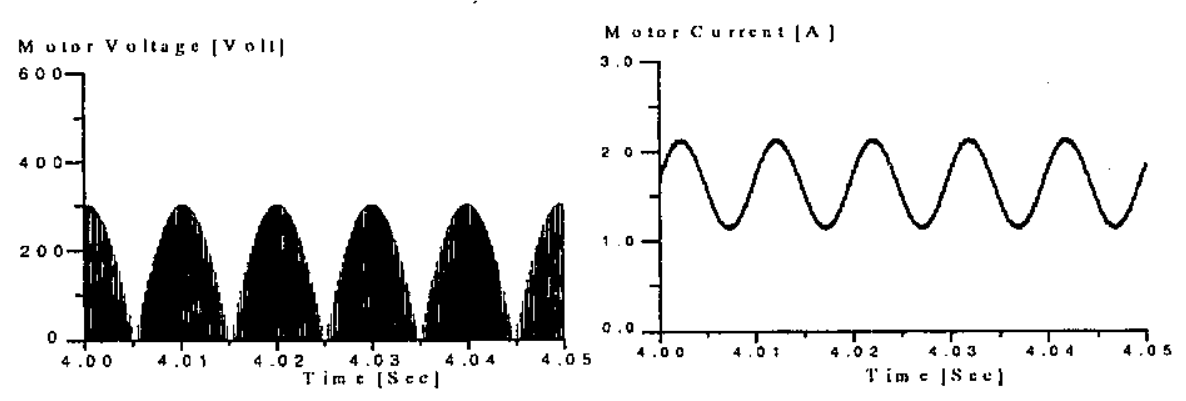

a. Simulation results.

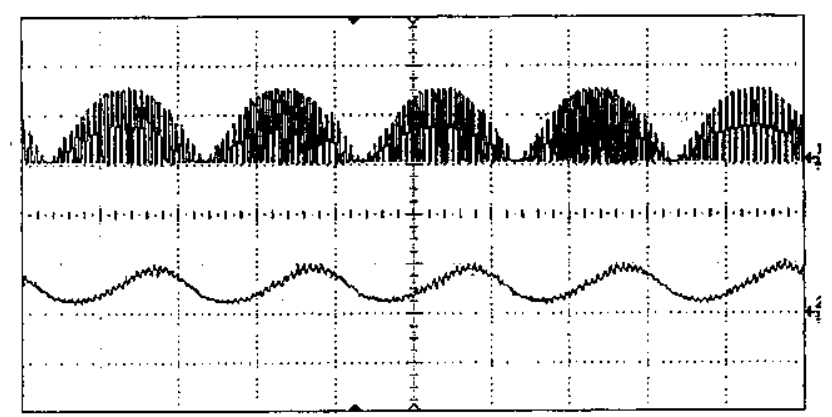

b. Experimental results.

Top: supply voltage $200 \mathrm{~V} /$ div Bottom: supply current $2 \mathrm{~A} / \mathrm{div}$

Figure 10. Simulation and experimental results for motor voltage and current versus time. 


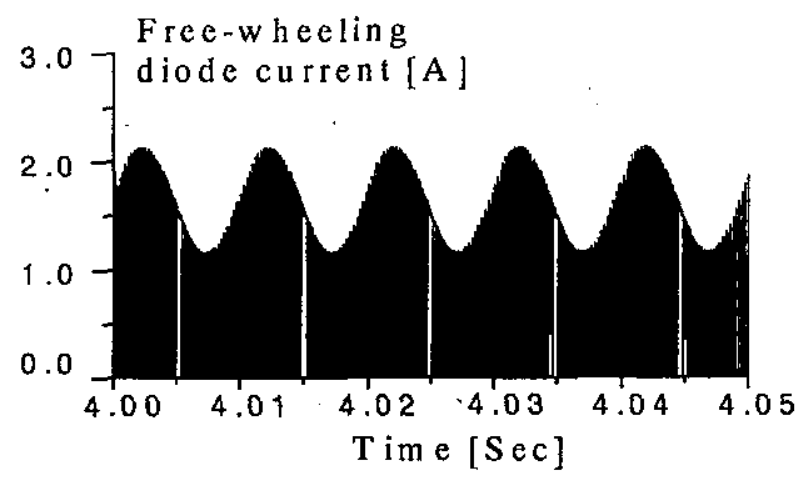

a. Simulation

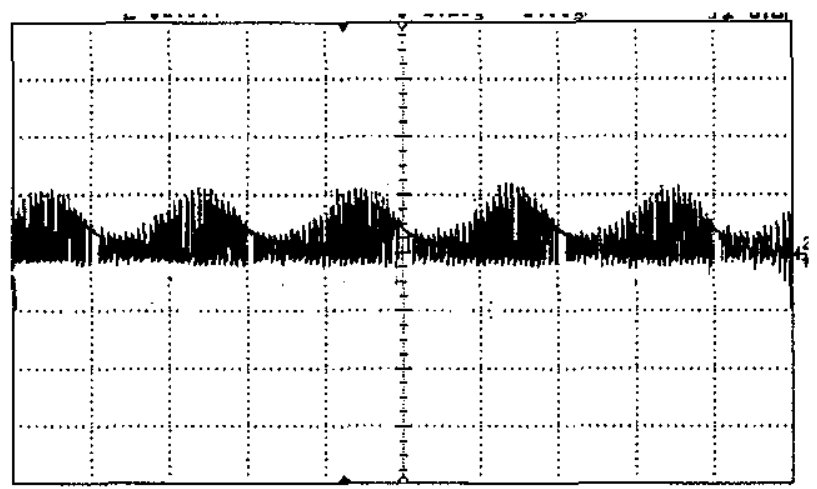

b. Experimental waveform (Current $2 \mathrm{~A} /$ div \& Time $5 \mathrm{~ms} / \mathrm{div}$ )

Figure 11. Simulation and experimental current waveform of the free-wheeling diode versus time.

\subsection{Run-Up Performance}

Figures(12-14) show the characteristics at run-up condition. These results are taken at full load with chopping frequency of $4 \mathrm{khz}$ and modulation index 0.6 . It is observed that the motor under test draws a starting current of twice its full-load current and starts within about 0.5 second.

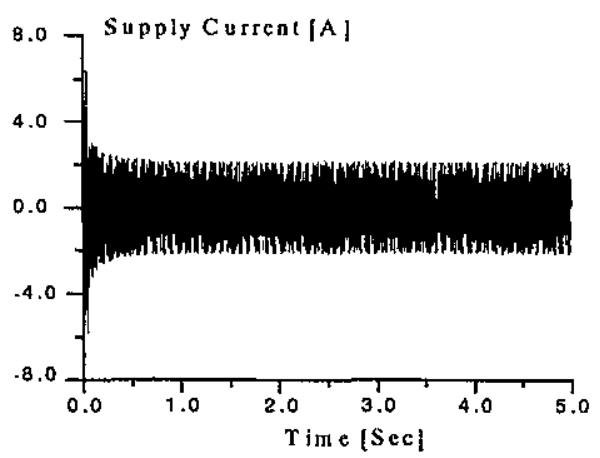

a. Simulation

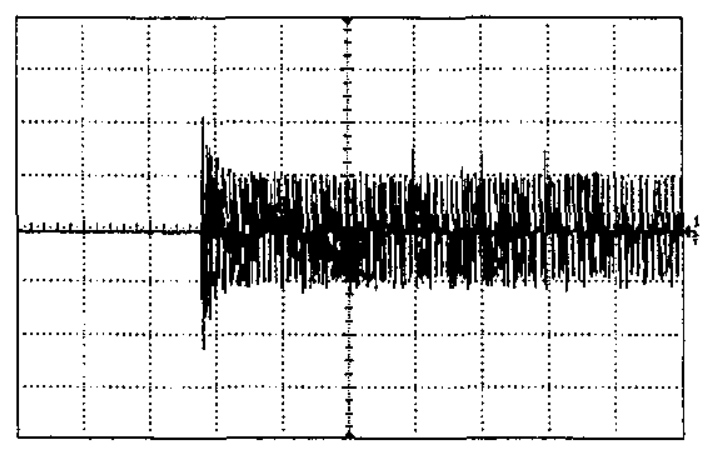

b. Experimental $2 \mathrm{~A} / \mathrm{div}$

Figure 12. Simulation and experimental for supply input current versus time during run-up. 


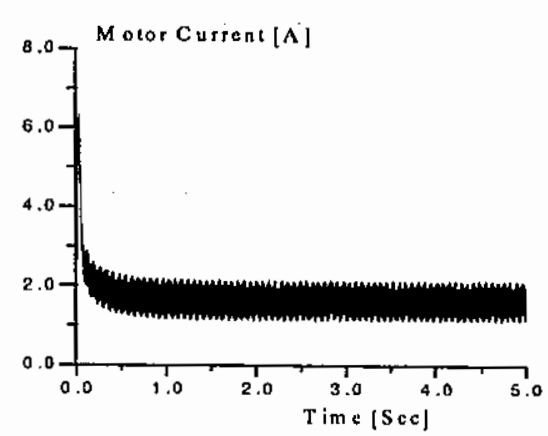

a. Simulation

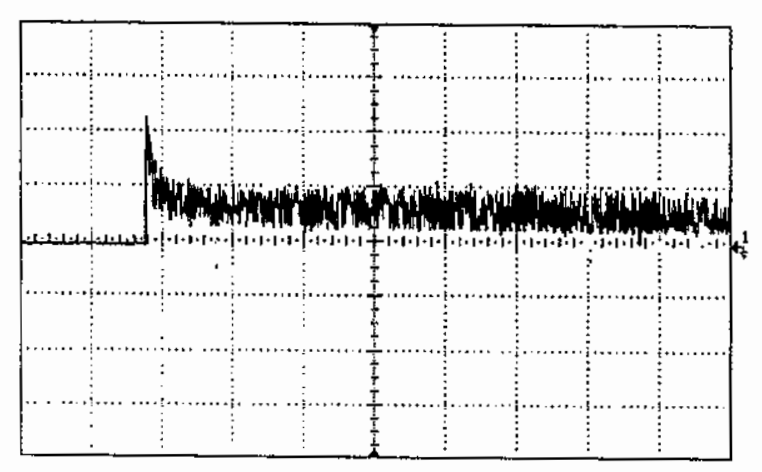

b. Experimental $2 \mathrm{~A} / \mathrm{div}$

Figure 13. Simulation and experimental results for motor current versus time during run-up.

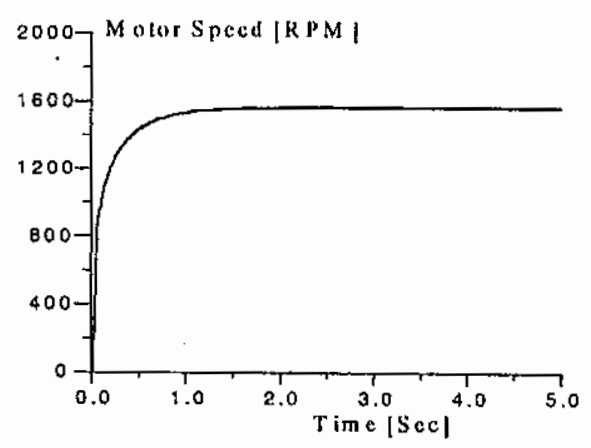

a. Simulation

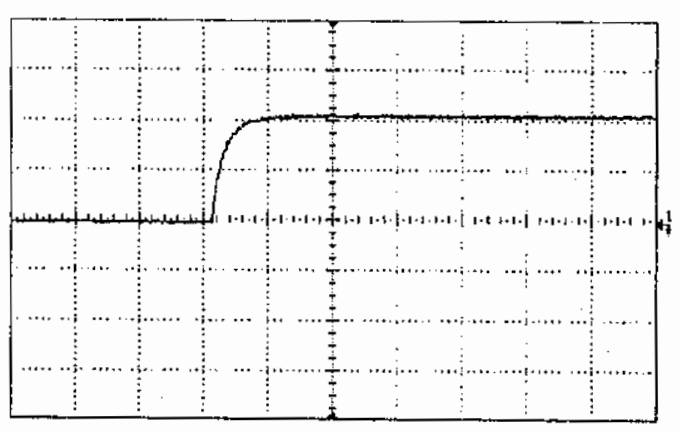

b. Experimental 750RPM/div

Figure 14. Motor speed versus time during run-up.

\subsection{Load Disturbances}

Figures 15,16 show the simulation and experimental results for the motor current and speed respectively versus time for the load change from half to full load. It is observed that the transient period lasts within about two seconds. Since the applied voltage is constant it is observed that the current is increased while the speed is decreased.

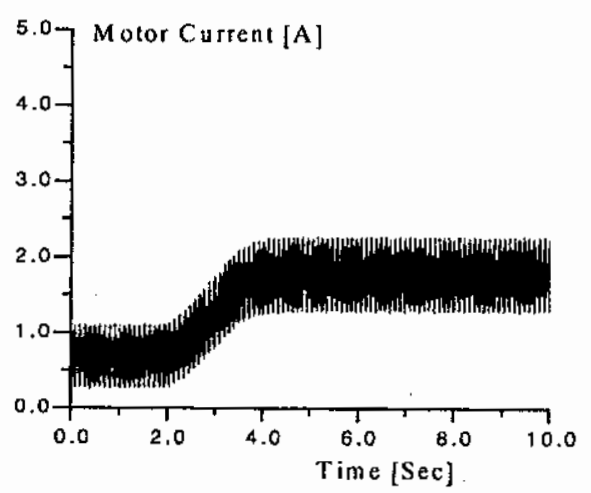

a. Simulation

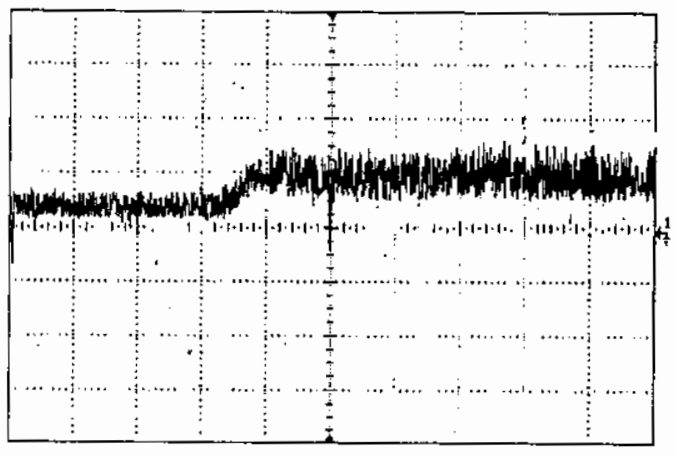

b. Experimental 2A/div

Figure 15. Simulation and experimental results for motor current versus time due to load change from half to full load. 

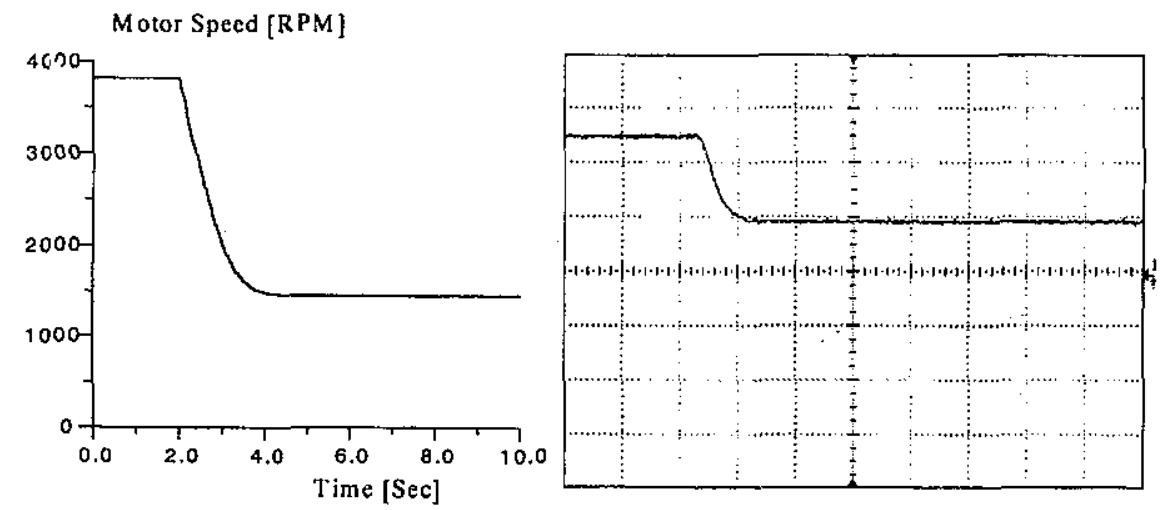

a. Simulation b. Experimental 1500RPM/div

Figure 16. Simulation and experimental results for motor speed versus time due to load change from half to full load.

\subsection{Improvement of Supply Waveforms}

Figure 17. shows the experimental waveforms of supply input voltage and current at the converter input using a filtering capacitor of 0.5 micro-Farad. It is observed that the supply current waveform is almost sinusoidal and the power factor is improved. Also it is noticed that this small capacitor value is sufficient due to high switching frequenty $(4 \mathrm{kHz})$. The chosen chopping frequency is a compromise between switching losses and input filter requirements, however, it was found that the required capacitor is smaller with higher chopping frequencies.

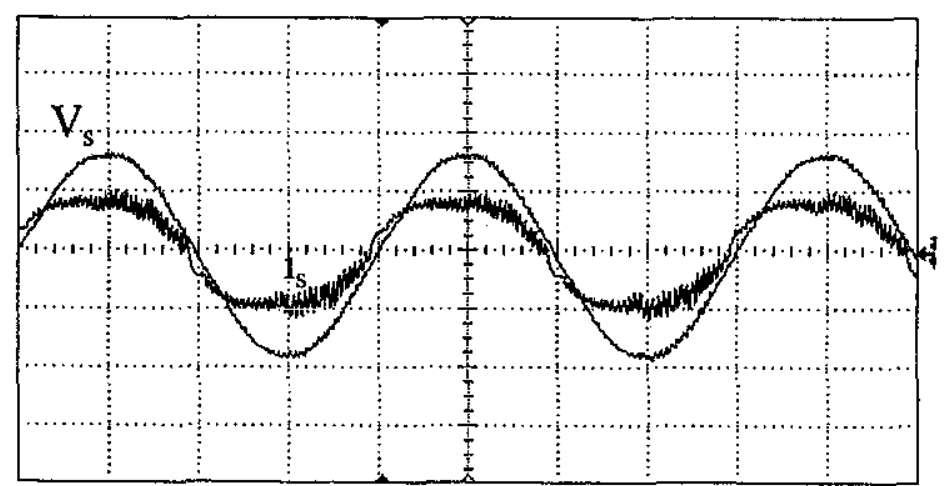

Figure 17. Experimental waveforms for common coupling supply voltage and current with using filtering capacitor.

\section{CONCLUSIONS}

In this paper an analytical and experimental study for steady-state and dynamic performance of a dc series motor fed from a single-phase AC-DC PWM converter has been proposed, for small and medium output power applications. The drive circuit for this system is simple and allows high chopping frequency, which facilitates the input filter requirements for supply current. It has been found that while the motor input voltage is constant over load range, the total harmonic distortion factor is quite small and almost constant. This allows the use of minimum value of filtering capacitor to operate the system with sinusoidal supply current at almost unity power factor. The 
system performance has been studied analytically and verified experimentally where close agreement between the computed and test results was achieved. The system has been tested using constant chopping frequency and modulation index however varying these parameters is possible and can be implemented in a closed loop system for speed control.

\section{REFERENCES}

[1] P. Enjeti, W. Shireen, P. Packebush and l.Pitel, "Analysis and design of a new active power filter to cancel neutral current harmonics in three-phase four-wire electric distribution system", IEEE Trans. Ind Application, Vol 30, No 6, PP1565-1572, Nov/Dec 1994

[2] R. Martinez and P. N. Enjeti, "A high-performance single phase rectifier with input power factor correction", IEEE Trans. on Power Electronics, Vol 11, No 2, PP 311-317, March 1996

[3] S. S. Shokralla, S. A. Mahmoud and H. Mekhaeel, "A sinusoidal pulse width modulated converter fed DC motor", The Fifth Middle East International Power Conference MEPCON'97, Alexandria, EGYPT, PP 292-301, Jan 4-6, 1997

[4] S. A. Hamed, "Steady-state modeling of a uniform pulse width modulated singlephase AC- to DC converter fed dc motor drive", ETEP, Vol 3, No 5, PP 379-386, September/October 1993

[5] S. Bisvas, B. Basak and M. Svamy, "A three-phase half-controlled rectifier with pulse width modulation", IEEE Trans. on Industrial Electronics, Vol 38, PP 121125, March 1991

[6] S. Bisvas, M. Mahesh and B. Lyenger, "Simple new PWM patterns for thyristor three-phase ac to dc converters", Proc. IEE, Vol 133, PP 354-358, 1986

[7] T. Katoka, K. Mizumachi and S. Miyairi, “A pulse width controlled AC to Dc converter to improve power factor and waveform of AC line current", IEEE Trans. on Industry Application, Vol 15, PP 670-675, 1979

[8] R. Itoh and $\mathrm{K}$ Ishizaka, "Single-phase sinusoidal converter using MOSFET's", Proc. IEE, Vol 136,Pt B, No 5, PP 237-242, Sept 1989

[9] S. Doradla, C. Naganani and S. Sanyai, "A sinusoidal pulse width modulated three-phase AC to DC converters fed DC motor drive", IEEE Trans. on Industry Application, Vol 21, PP 1394-1408, 1985

[10] Dialo, S. A. Mahmoud and R. Doeuff, "Digital simulation of a thyristor-chopper controlled dc series motor", IASTED Simulation 82, Paris, 29 June- 1 July 1982

[11] Rashid, "Dynamic responses of dc chopper-controlled series motor", IEEE Trans. on Industrial Electronics and control Instrumentations, Vol IECI-28, No 4, November 1981

[12] Dubey and W. Shepherd, "Transient analysis of chopper fed dc series motor", IEEE Trans. on Industrial Electronics and control Instrumentations, Vol IECI-28, No 2, May 1981

[13] Yablon and J. Appelbaum, "Transient analysis of a dc series motor, linear versus non-linear", IEEE Trans. on Industrial Electronics and control Instrumentations, Vol IECI-28, No 2, May 1981

[14] El-Khouly, F. Gebril and A. S. Abdel-Ghuffar, "Dynamic responses of dc chopper-controlled series motor", Al-Azhar Engineering Second International Conference, December 12-24,1991 


\section{APPENDIX}

Motor Data And Parameters:

$0.5 \mathrm{HP}, 220 \mathrm{~V}, 3.6 \mathrm{~A}, 4000 \mathrm{rpm}$, series motor of the following measured parameters:

$\mathrm{R}_{\mathrm{a}}=3.4 \Omega, \mathrm{L}_{\mathrm{a}}=0.1178 \mathrm{H}, \mathrm{R}_{\mathrm{f}}=2.9 \Omega, \mathrm{L}_{\mathrm{f}}=0.2753 \mathrm{H}$

$\mathrm{F}=0.00012 \mathrm{Nm} / \mathrm{rad} / \mathrm{Sec}$ and $\mathrm{J}=0.007 \mathrm{Kg} \cdot \mathrm{m}^{2}$

The Magnetization Curve Parameters

$\mathrm{I}_{\mathrm{sa}}=0.8 \mathrm{~A}, \mathrm{~B}=0.02199, \mathrm{~K}_{\mathrm{o}}=0.525$ and $\alpha=0.3000$

The Source Impedance Parameters:

$\mathrm{Rs}=0.2 \Omega$ and $\mathrm{Ls}=0.003$ henery

The chopper parameters:

Chopper period $\tau=0.25 \mathrm{mSec}$ and $\mathrm{NT}=40$ 


\title{
الخواص الايناميكية والمستثرة لمحرك توالى مغذى من مغير تعديل عرض النبضة
}

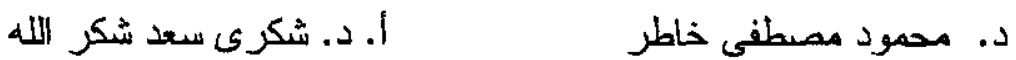

$$
\text { قسم الهندسة الكهربية - كلية المهنسة بشبين الكوم - جامعة المنوفية }
$$

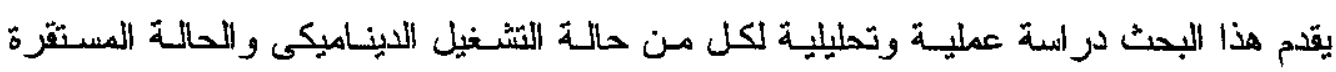

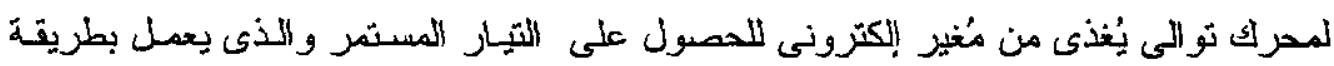

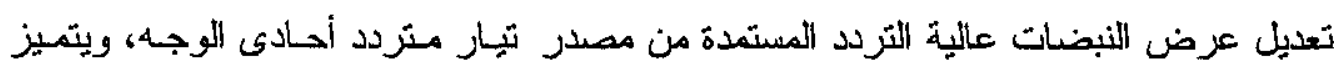

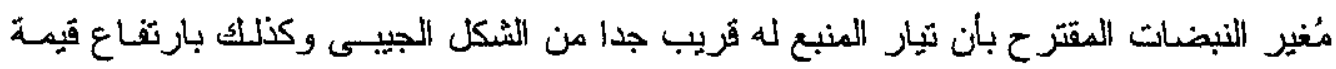

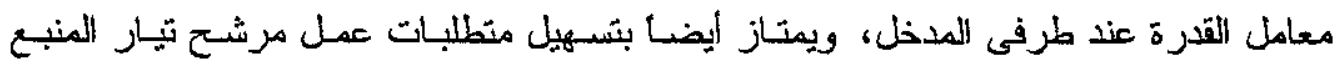
وذلالك لاستخدام التردد العالمى للقطع.

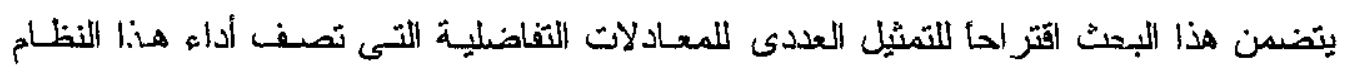
تحت ظروف التشنيل المختلفة حيث ثم الأخذ فى الاعثبار ثأثير كل من معاوفـة منبع التخذية وتشبع القلب الحديدى للمحرك، وللتأكد من صحة هذه الدر السة تم بناء منظومة اختبـار معمليـة

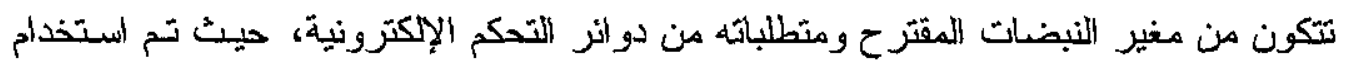
هذه المنظومة في تغذية واختبار محرك التو الىى تحت ظروف ومن التشغيل المختلفة.

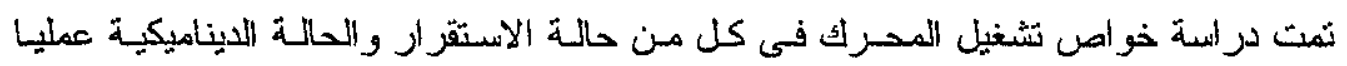
وتحليليا، حيث تم دراسة تاثير تغييز عزم الحمل و عملية بدء الحركة وكذلك الحالات العسابرة

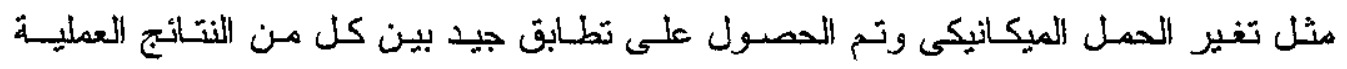
و التحليلية، الأمر الذى يجعل من الممكن إجراء مثل هذه الأراسة على الأنظمة الأخرى الأكثر

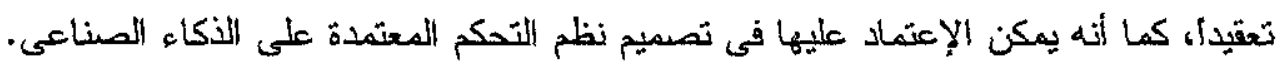

